\title{
The Economic Face of International Co-operative Arrangements: The Cases of IBSA and CPLP
}

\author{
Ariane Roder Figueira* \\ Bernardo Frossard da Silva-Rêgo**
}

\begin{abstract}
The formation of international co-operative arrangements with different scopes and structures has been growing in the international system. Brazil has frequently participated in these groups, forming a complex diplomatic framework where it coexists and interacts with regional blocs, international organisations, groups, and coalitions. Therefore, the purpose of this article is to investigate the commercial effects provoked by the international co-operative arrangements, observing in particular two cases from the Brazilian point of view: IBSA (India-Brazil-South Africa Group) and CPLP (Community of Portuguese Language Countries). The theoretical constructs of the New Institutional Economy formed the basis of the interpretation of the data, and the literature that explores new mechanisms of external insertion of emerging countries was highlighted through the diplomacy oriented towards the South-South axis. The methodology comprised the study of two cases, bringing together both quantitative and qualitative indicators based mainly on the official reports of the Brazilian government and sectoral analyses produced by trade associations. The intrabloc trade evolution was performed through a cluster analysis considering the exports and imports of each of the cases investigated in relation to Brazil. The results reached showed an increase in trade transactions between member states.
\end{abstract}

Keywords: International Co-operative Arrangements; IBSA; CPLP; Institutional Theory; SouthSouth; Cluster Analysis; International Trade.

\section{Introduction}

The contemporary international system has been gaining increasingly more complex and dynamic contours. The phenomenon of globalisation gives rise to something new every day in international relations, combining traditional phenomena such as inter-state con-

\footnotetext{
* Federal University of Rio de Janeiro (UFRJ), Rio de Janeiro-RJ, Brazil; ariane.roder@coppead.ufrj.br. ORCID iD 0000-0002-2900-3040.

** Federal University of Rio de Janeiro (UFRJ), Rio de Janeiro-RJ, Brazil; bernardo.frossard@coppead.ufrj.br. ORCID iD 0000-0003-4475-3920.
} 
flicts typical of an anarchic and asymmetric environment with increasingly sophisticated and diverse co-operative arrangements. In this context, multilateral international organisations, regional integration blocs, permanent and ad hoc coalitions, strategic alliances, and other entities involving governments and non-state players coexist together.

Castells (2005) called this entanglement of circumstances that coexist and interact a 'network society' with global, horizontal, and multifaceted structures. Keohane and Nye (1998) in turn designated this new configuration of the international system of the second half of the $20^{\text {th }}$ century a 'complex and asymmetrical interdependence' whose correspondence lies in the fact that the states are progressively more dependent on one another, with reciprocal costs, but asymmetric in nature (assuming the difference in power of these states considering the international system). Krasner (2012) has highlighted the role played by the growing number of international regimes and multilateral organisations that emerge in this new context, helping to create a less hostile environment that is more deeply rooted in co-operative structures and actions, creating a positive feedback loop more prone to peace.

Within this perspective of international relations, which became known as (neo) institutionalism, international co-operation is stimulated by the institutions that, to a certain extent, help to shape the behaviour of the players either by encouraging or by constraining certain actions. In this sense, the creation of standards reduces mistrust among the states, increasing the predictability of action and creating conditions for mutual trust and the development of joint actions aiming at win-win results.

Also, in addition to improving the relationship among the states, authors of the 'new institutional economics' school also highlight the role of institutions in the advancement of international trade relations. North (1990), for example, analyses the role of the institutions in fulfilling two main tasks: reducing transaction costs and reducing the costs of processing the information needed for the companies to make decisions. In the same direction, Mudambi and Navarra (2002: 636) emphasise that the importance of institutions derives from the fact that 'they represent the main immobile factors in a globalised market'. Thus, in an international environment characterised by the mobility of firms and factors of production, the legal, political, and administrative systems tend to be the internationally immobile framework whose costs determine the attractiveness of the location of companies. In this way, the institutions influence the ability of firms to interact and thus affect transaction costs and the co-ordination costs related to production and innovation. The specific characteristics of the institutions in this way shape the incentives faced by private companies and, as a consequence, they also influence the degree of external direct investment (Mudambi and Navarra 2002).

Particularly for emerging economies, the institutions, as pointed out by Cherchye and Verriest (2016), play an even more relevant role in the flow of trade, because a fragile institutional environment can repel foreign investment and undermine the competitive advantages of domestic firms operating in the international market. The inverse is also observed, which is when the institutional variables stimulate trade growth, creating a healthier and more predictable environment for business development. 
Thus, supported by this debate that observes the impact of international institutions on increasing mutual trust, on predictability, and on reducing transaction costs as important components for enhancing the flow of international trade, the purpose of this article is to analyse in a more focused way the economic and financial results leveraged by international co-operative arrangements, observing in particular from the Brazilian perspective two groups in which the country is an interested party: India-Brazil-South Africa Group (IBSA) and the Community of Portuguese Speaking Countries (CPLP). To do so, some categories were selected for analysing the documentary and bibliographic data in a longitudinal format, such as bilateral and multilateral agreements signed between the parties in the commercial field, export and import rates, and the profile of Brazil's export agenda with countries in the groups.

When mapping the studies in the area, it is possible to notice the existence of an interpretative gap left by the literature that does not include comparative analyses between these two groups of countries. In addition, few studies have focused on observing the economic data produced in an endogenous (intra-group) character, but rather they are particularly directed to one of these groups and not to both (Schor and Onuk 2015; Fonseca, Azevedo and Velloso 2005; Ferreira Filho and Castro 2012). Particularly on the India-Brazil-South Africa Dialogue Forum, much of the debate focuses on the role played by the medium powers in the formation of horizontal co-operative arrangements and on setting up the preferences of these agents considering the contemporary international architecture (Guimarães 1998; Ramanzini, Mariano and Almeida 2015; Leite 2011; Saraiva 2007; Lima 2009). There are also those who have tried to understand the origin of this arrangement (IBSA), the singularities of these countries (Faria, Nogueira and Lopes 2012), and the convergences of interests among them, as well as the coherence between the parties in their positions in international organisations (Oliveira, Onuki and Oliveira 2006; Moura 2008).

As for the CPLP on the other hand, the recurrent objectives of the research have been to highlight the history of Brazil's diplomatic relationship with the African countries (Pimentel 2000; Rizzi 2016; Saraiva 2002), the technical co-operation agreements based on the constitution of the arrangement, the bilateral ties with some of the African States such as Nigeria, Angola, and South Africa (Penna Filho 2008; Pereira 2010), and the Brazilian investment profile in this region (Santana 2003).

Based on these debates, but proposing a different angle in the analysis, the fundamental question that permeated the entire preparation of the study was the following: Do the international co-operative arrangements of a non-economic character essentially have the capacity and potential to generate economic and financial effects for the states which are a part of them? To support this debate, parameters were sought in the theoreticalconceptual postulates of (neo) institutionalism to investigate whether the institutions, by promoting the co-ordination of preferences, by increasing the predictability of action of the other state, by improving the flow of information and general norms, and by enabling a more stable environment, would promote the intensification of trade and investment flows between the parties involved. 
Thus, the article in the first part seeks to detail the central foundations that guide institutionalist thinking, especially applied to the debate of international economy. After this, the methodology used to prepare the cluster analysis is presented. Next, the cases investigated (IBSA and CPLP) are presented detailing the particularities of each arrangement with a particular focus on the analysis of the commercial variables mentioned above. Finally, an analysis is carried out integrating the data and the literature listed.

\section{The role of institutions in the flow and development of international trade}

The 'new institutional economy' (NIE), as it is now known, emerged as a current theoretical alternative to neoclassical economic thought, whose premises are rooted in the economic rationality of the agents (who act according to a relational calculation considering the costs and inherent benefits of the action), in the perfect functioning of markets, and in the symmetry of the information within a competitive environment. Contrary to this view, North (1990), one of the main exponents of (neo) institutionalism, understands that markets are empirically imperfect and that the rationality of agents is limited, which means that the information received is rarely complete and that individuals have different mental models concerning the world's functioning, as is also pointed out by Harris, Hunter, and Lewis (2003).

In this context, institutions play a key role in reducing transaction costs and the uncertainties surrounding markets and information because the information that each organisation has is asymmetric and, because of this, expensive. In this way, the costs of measuring the various dimensions of the products or services offered, or the performance of the economic agents and the costs of executing contracts, determine the transaction costs. Therefore, institutions are important when the cost to transact is high (North 2003).

In a complementary way, Peng (2006) and Scott (2008) affirm that, although institutions have several functions, their key role is to reduce uncertainties and provide meaning. In this sense, they do so for different players, conditioning the rules and standards that regulate behaviour while defining the limits for what is legitimate. These players, on the other hand, are guided by their interests and make their choices within an institutional framework set by the environment (Lee, Peng, and Barney 2007).

For Mudambi and Navarra (2002), however, institutions facilitate economic growth, international investment, and trade in two ways. First, they reduce opportunism among players that do not know each other, and second, they provide a reputation-building model that is supported by credible enforcement, monitoring, and co-ordination structures. In this way, markets that are similar in political structure, market structure, or culture represent less uncertainty, so therefore entry costs are relatively lower. Investors would therefore be more likely to enter countries where the political regime is relatively easy to predict (Vernon 1971, cited in Mudambi and Navarra 2002). Likewise, investors are less likely to enter countries that are culturally distant and have different organisational structures (Hanson II 1999). 
According to Globerman and Shapiro (1999), these institutional differences are significant for multinational companies operating within different institutional contexts. In the case of emerging countries, weak institutional arrangements may increase the information asymmetries and because of this, firms face higher related risks (Meyer 2001) and need more resources in search of information (Tong, Reuer and Peng 2008). In this context, according to Peng and Heath (1996), in places where the legal institutions are weak, firms should rely more on relationship-based strategies such as with other firms, with distribution agents, or with government officials.

Thus, the focal point in the NIE is the impulses given to economic activity by the institutional environment' and by the 'governance institutions. These 'rules of the game' may be incentives or disincentives to economic activity, determining in turn what types of governance structures are most economically efficient. Governance structures are also called 'institutional arrangements' and have to do with organising decision-making schemes. The transactions occurring at the governance level are also accompanied by transaction costs, considering that the level of these costs influences the level of economic activity, which in turn determines what kind of governance structure is the most efficient (Williamson 1975).

Therefore, the international co-operative arrangements, in light of this theoretical perspective, play a fundamental role in determining the location of the investments and in defining the strategies for entering the international market, which are understood as the combination of where, when, and how to enter. Perera (2015) offers a model that summarises these interactions between the institutional environment and the trajectory of the companies.

Figure 1: International trade agreements' influence on institutional environment

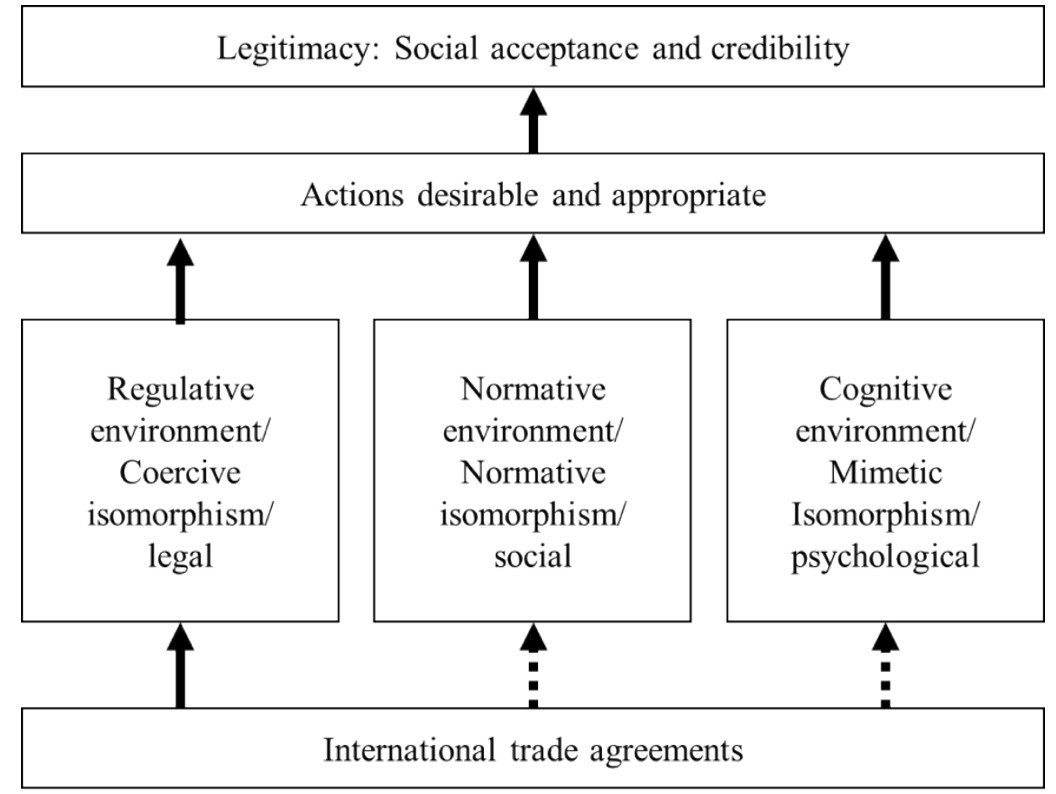

Source: Perera (2015: 209). 
According to Perera (2015), international trade agreements directly provide the regulatory environment in which companies will be inserted and, indirectly, the normative and cognitive/mimetic aspects. The behaviour desired is obtained by the companies based on the format of this institutional environment, which in turn provides legitimacy for their performance. In this sense, when shaping the institutional environment, these agreements have the property of providing greater acceptance and giving stronger credibility to the performance of these companies at an international level.

In this case, the following elements are understood as making up the institutional environment: normative aspects, formal and informal rules, regulatory barriers, policies encouraging the entry or issuance of direct investments, intellectual property rights, stability of the governmental arrangements whether of the country of origin or host country, and bilateral or multilateral international agreements, among others. In a complementary direction, when studying the correlation between the foreign direct investments (FDI) of Japanese companies and the commercial agreements under which the country is inserted, Ishido (2016) reinforced the need to focus mainly on the political, cultural, and institutional issues and the context of trade liberalisation before even probing more deeply into the interpretation of the factors endogenous to the company that involve the entire process of internationalisation.

\section{Methodology}

The methodology used involved the study of two cases (IBSA and CPLP), bringing together both quantitative and qualitative indicators based mainly on the official reports of the Brazilian government and of the groups. To do so, some categories were selected for analysis of the documentary and bibliographic data in a longitudinal format such as 1) the bilateral and multilateral agreements made between the parties in trade and customs, 2) trade exchange rates, and 3) the profile of the export agenda.

The longitudinal analysis was carried out considering the official framework of multilateral co-operation of each of the cases investigated from the Brazilian point of view, meaning that the relations of each of the member countries were mapped only with Brazil, thus excluding the trade interactions between the other countries of the group. Furthermore, a statistical technique known as cluster analysis was used in order to help answer the question regarding the commercial gains provided by IBSA and CPLP for Brazil, whose aim is to identify associations between the objectives in order to discover clusters, either of similarities or of dissimilarities. In other words, this means that this method allows an object to be observed in perspective compared to others, identifying proximities (or distances) and clusters of similar subsets (Pohlman 2007). This method has been used recurrently within the areas of political science and international relations, exploring diverse themes such as the democratic profile of countries (Coppedge, Alvarez and Maldonado 2008), the relationships between politics, economics, and conflicts (Wolfson, Madjd-Sadjadi and James 2004), comparative studies of international trade (Vahalík and Staníčková 2016), and relations between corruption and global firms (Grein, Sethi and Tatum 2010). 
Thus, the variables of exports and imports in each of the axes were observed in order to check the trade growth of the CPLP and IBSA countries with Brazil. The data were observed in the period before the formation of each of these arrangements and after their respective constitutions in an attempt to observe if there was a substantive increase in the commercial interaction among the members when compared with the previous period. So, for the IBSA case, the comparison was between the sum of the $\mathrm{x}$-axis exports and the $y$-axis imports until 2003 at the earliest, and those same variables after 2003 until 2016. In the case of the CPLP, the cut-off year was 1996, and from there the same standard of analysis was used as in the previous case.

Also, in order to integrate the cluster analysis, the pairs were used as comparison parameters, and it was possible to obtain a visual form of assessing the comparative gains of each country. The states selected for the analysis were the participants in each of the agreements, as well as countries in the same region of those participants, namely, in Africa, South and Southeast Asia, and Europe, since countries in the same region tend to have physical distances and psychic similarities in relation to Brazil. And because they are from the same regions, they also tend to have baskets of similar export and import products. Thus, this set of countries that does not belong to any of the cases investigated were included as control groups, indicating if there was a commercial expansion (import and export) in the same proportion as the member countries, and with this being able to show in these cases if the creation of co-operative arrangements did make a difference in advancing trade.

It should also be noted that some strategies were adopted to avoid distortions in the data analysis such as removing, in the case of Asia, countries that could distort the chart given the size of their trade with Brazil, as were the cases of China and Japan. These countries have a large volume of exports and imports with Brazil, and because of this reduce the differentiation between the other countries that have a commercial flow on a smaller scale. Following the same logic, to control the CPLP, it was necessary to do a separate study for Portugal since the value traded by European countries with Brazil distorted the clusters when aggregated to the African countries. So, again, to avoid statistical distortions, the African countries became a specific cluster. Other points worth mentioning are the absences in the statistical analysis of East Timor, which only came into being as a country in 2002, and of Equatorial Guinea, which joined the CPLP only in 2014, which means that they did not participate as members of the time series investigated, making it therefore necessary to exclude them from the statistical analysis to avoid distortions in the results.

The collection of data on the values of Brazilian exports and imports with each country was obtained from the United Nations trade statistics website (UN Comtrade 2016). Furthermore, the logarithmic value of each of these variables was used in order to improve the graphical aspect. From that point on, a scree plot was built to obtain the clusters, where three clusters were selected for the IBSA and four for the CPLP and Portugal from the points where the eigenvalues presented a linear downward trend, called the elbow rule. The cluster graph was plotted for before and after the agreements were signed using the $\mathrm{R}$ software cluster package, thus allowing the visualisation of Brazil's trade gains with the IBSA and CPLP countries. 


\section{Presentation and data analysis}

The formation of co-operative arrangements of the South-South (horizontal) type emerges as a result of post-World War II international dynamics characterised primarily by the joint search by developing countries for better results in the multilateral international negotiations through a common agenda. If, initially, in the mid-twentieth century, arrangements of this nature aimed at recomposing the order of the East-West global conflict (established according to the security agenda) on the North-South axis (prioritising the development agenda), in the post-Cold War scenario, these arrangements were spread out, rearranged, diversified, and given new garments that began to permeate the debates between centre and periphery (Leite 2011).

This movement to establish horizontal partnerships among developing countries was experienced by Brazilian foreign policy in different moments of its trajectory and in a discontinuous format. Although the main objective of leveraging the country's economic development has been maintained over the past 50 years, the strategies to achieve it have changed significantly from government to government (Saraiva 2002), thus revealing distinctions in the treatment and the prioritisation attributed by the diplomatic corps to the African and Asian countries, which typically were far from the Brazilian radar. Despite this, Brazil, characterised as a medium power in the international system, has stood out especially in the last decade as a political entrepreneur in building co-operative arrangements of different types with a view towards amplifying the dialogues of the South. With that in mind, both the IBSA group (India, Brazil, and South Africa) and the CPLP can be considered the result of this involvement.

\section{CPLP: going beyond its original proposal}

The CPLP countries are connected by habits, culture, and language, among other factors arising from the Portuguese colonisation, but they are distant when one considers the historical paths, the domestic orders, and the role they play in the international system. These differences, however, did not prevent co-operative ties from being formed among them.

The initial approximation of Brazil with some of these countries, for example, took place even before the process of independence of the Portuguese colonies in Africa. Portugal, on the other hand, only experienced a rapprochement with its former colonies in the late 1980s, when it proposed starting negotiations to form a co-operative arrangement among the Portuguese-speaking countries in the $2+5=7$ modality (Rizzi 2016). In other words, it meant that Portugal promoted a mechanism that would differentiate its country and Brazil from the other Portuguese-speaking African countries (PALOPs), which was not accepted by Brazilian diplomacy, which defended and was victorious in its proposal to guarantee a multilateral partnership between the parties of $7=7$.

This mechanism resulted initially in the International Institute of Portuguese Language (1989) and later in the constitution of the CPLP in 1996, which was backed by two arguments essentially of interconnection between the peoples: culture and the South 
Atlantic. Its formation was constituted by Angola, Brazil, Cape Verde, Guinea-Bissau, Mozambique, Portugal, and São Tomé and Príncipe and, later, by the accession of East Timor and Equatorial Guinea. Since then, heads of state have come together every two years to assess progress and propose new projects for the community. Although these meetings have taken place with the regularity planned, the institutionalisation of the group occurred late, and its bylaws were formalised only in 2007, more than ten years after its creation. It was in this document that the operationalisation of the different areas was determined and the objectives were defined more clearly, outlining in general terms the role to be played by the community, such as political-diplomatic concertation, co-operation in all domains, and the promotion of the diffusion of the Portuguese language (CPLP 2007).

Regarding this second axis in particular, the search for an approximation between countries in commercial terms is worth highlighting. The first major debate in this area came in 2000, when the heads of state in the declaration on 'Cooperation, Development, and Democracy in the Age of Globalization' agreed to develop mechanisms to deal with the globalised market, stating the commitment to eradicate poverty and promote sustainable development (CPLP 2010). This movement resulted years later in the establishment of the Meeting of Ministers of Trade of the CPLP countries with the purpose of negotiating measures to promote intra-group trade. At this meeting in 2012, through the Declaration of Luanda (CPLP 2012), the ministers presented the following lines of action:

a. Focus on economic and business co-operation in Clusters and Development Sectors of common interest to CPLP member states, namely: Knowledge (Research \& Development), New Technologies, Agriculture \& Rural Development, Infrastructure, Sea \& Natural Resources, Energy, and Tourism.

b. Implement measures to make it possible to overcome the structural difficulties to the development of Trade and Investment in four fundamental pillars that shall constitute the axes of economic co-operation in the CPLP: (i) improvement of the business environment for promoting trade, (ii) improvement of the business environment for investments, (iii) institutional and business capacity building, and (iv) improvement of financing mechanisms.

In 2016, the group of ministers met again, but no concrete measures resulted from the meeting. There was only a discussion on the details of the recommendations and targets established previously. As can be seen in Figure 2, this slowdown in the evolution of CPLP's trade agenda is reflected in the results of the group's commercial exchange, which has been increasing, but is still limited when analysed globally.

When bilateral acts between Brazil and the CPLP countries are considered on the other hand (since there are no multilateral acts), few are related to trade or customs. As for the former, there are only acts with Angola (1), Cape Verde (1), Guinea-Bissau (1), and Portugal (2), all of them dating before the creation of the community. As for the customs acts, there are only two with Portugal (2000 and 2001) according to Table 1. 
Figure 2: Brazil's commerce flow with CPLP as a percentage of Brazil's total commerce flow

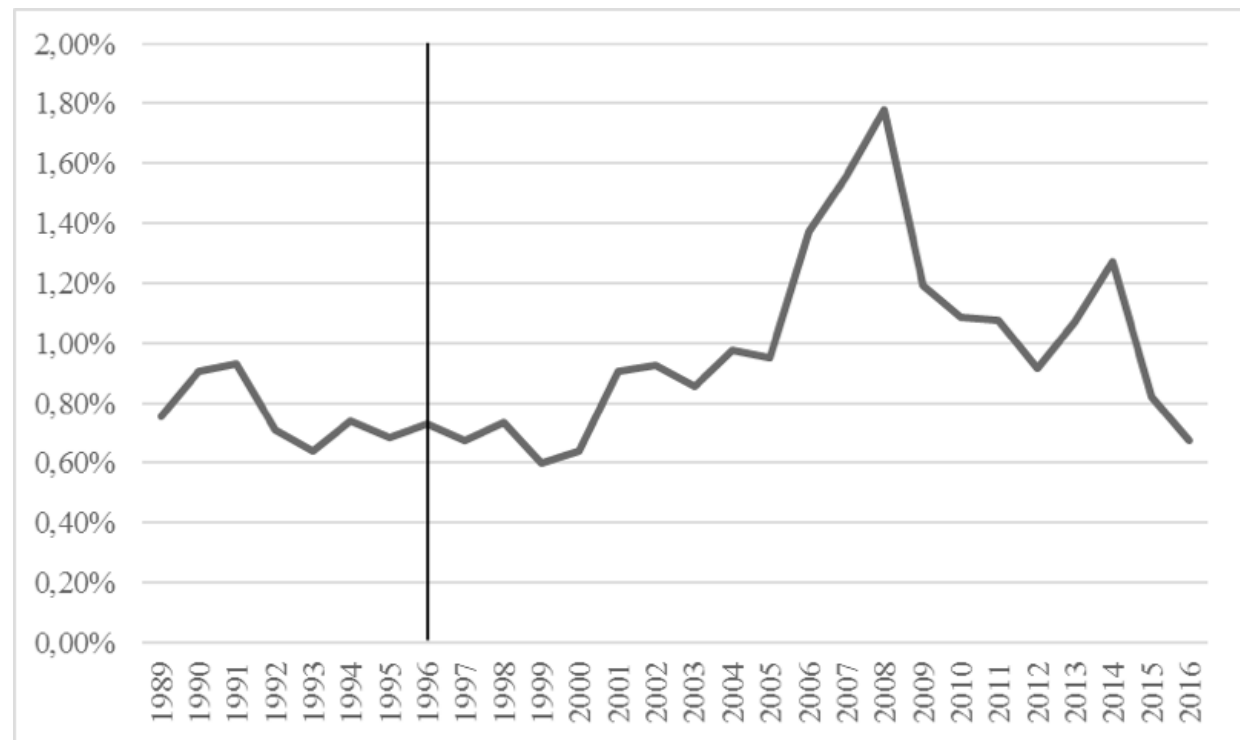

Source: MDIC (2016).

Table 1: Number of commercial/customs agreements and other agreements between Brazil and CPLP countries

\begin{tabular}{lllll}
\hline Countries & $\begin{array}{l}\text { Commercial } \\
\text { agreements (until } \\
\text { 1996) }\end{array}$ & $\begin{array}{l}\text { Other agreements } \\
\text { (until 1996) }\end{array}$ & $\begin{array}{l}\text { Commercial } \\
\text { agreements (post } \\
\text { 1996) }\end{array}$ & $\begin{array}{l}\text { Other agreements } \\
\text { (post 1996) }\end{array}$ \\
\hline Angola & 1 & 8 & 0 & 38 \\
Cape Verde & 1 & 12 & 0 & 39 \\
Guinea-Bissau & 1 & 12 & 0 & 21 \\
Equatorial Guinea & 0 & 1 & 0 & 4 \\
Mozambique & 0 & 9 & 0 & 72 \\
Portugal & 2 & 48 & 2 & 32 \\
São Tomé and & 0 & 5 & 0 & 34 \\
Príncipe & 0 & 5 & 0 & 35 \\
East Timor & $\mathbf{5}$ & 0 & $\mathbf{2}$ & $\mathbf{2 7 5}$ \\
CPLP & & $\mathbf{9 5}$ & Source: MRE (2016). &
\end{tabular}

It is worth mentioning that despite not having an essentially commercial focus, most of the 'other agreements' between Brazil and the countries of the CPLP have an economic or commercial counterpart for Brazil, such as infrastructure agreements. Despite this, an increase in the trade flow from Brazil to the CPLP countries can be seen when compared to their peers (i.e. other African or European countries).

Figure 3 shows the increase in Brazil's exports and imports with the CPLP countries (shown in the chart) in relation to their peers, which may be an indicator of trade gains 
because of this agreement with some countries taking the lead in this interaction. In this case, Angola is closer to the main Brazilian partner on the continent, Nigeria, and both Mozambique and Cape Verde are beginning to export more to Brazil and, therefore, are getting close to the figures of countries such as Cameroon and Senegal. Guinea-Bissau on the other hand has an increase in exports and imports and is approaching Zambia and Burkina Faso. São Tomé and Príncipe has joined Brazil's partners, but is still far behind its peers, while it is hard to make any interpretation of the positioning of Equatorial Guinea, which only joined the group in 2014, and of East Timor, which became a country in 2002.

Figure 3: CPLP country cluster, except Portugal, before and after the agreement

(1989-1995; 1996-2016)

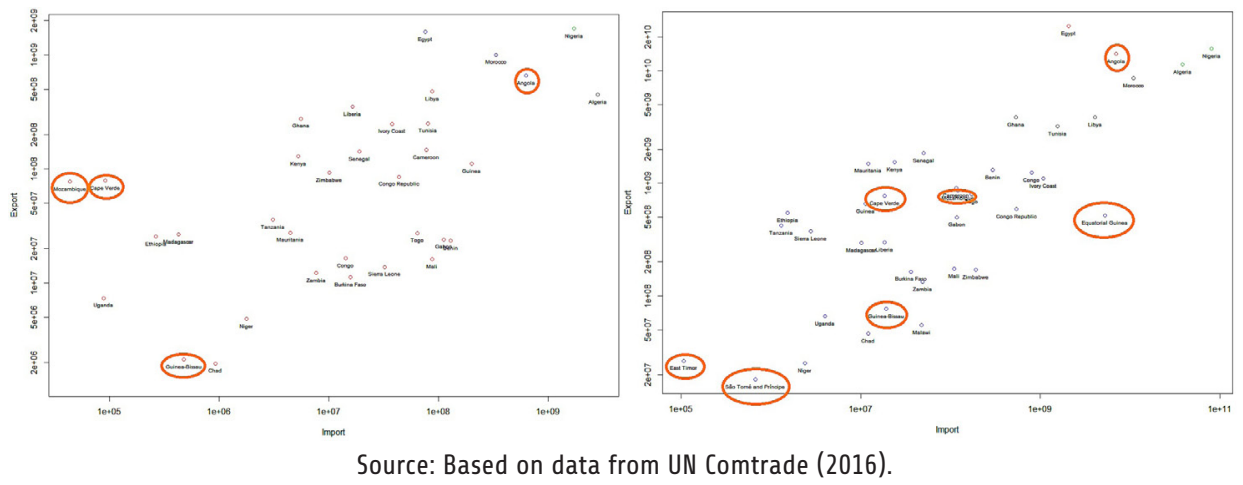

In Figure 4 one can see that Portugal has an intermediate position in Europe. However, this country becomes distant from the largest exporters after 1996, which indicates that its relative position after the CPLP agreement worsened when compared to other European partners. This can, however, be explained by the export agenda and the added value exported from goods from the other countries, considering that Brazilian exports are mainly agricultural, food, and mineral fuels while the imports from Portugal are concentrated in copper ores, fish, fruit, hydraulic cements, olive oils, wine, iron wires, and steels. The presence of Brazilian companies in Portugal is great when compared to the other countries of the CPLP, since this country is considered by the entrepreneurs, in most cases, as a 'gateway' to Europe due to the smaller mental distance. Among these companies are Embraer, WEG, Companhia Siderúrgica Nacional, Marcopolo, Odebrecht, Camargo Corrêa, Andrade Gutierrez, and Haco (MRE 2013). Despite this decline compared to the period prior to setting up the arrangement, Portugal still stands as Brazil's main trading partner within the scope of the CPLP, since there is a historical partnership between both countries and, as mentioned previously, the country is the main gateway into the European market.

The second largest partner, whose current trade sometimes exceeds that of Portugal, is Angola. According to data from Itamaraty's Trade Promotion Department released in 2012, there are more than 40 Brazilian companies operating on Angolan soil, with the main one being Odebrecht, which has been in the country for 25 years. Other contractors such as Camargo Corrêa, Andrade Gutierrez, and Queiroz Galvão have also strength- 
ened their presence in this country, taking advantage of the special credit lines opened by the BNDES (Brazilian Development Bank) for Angola, mainly directed to infrastructure building projects. The other companies, according to the Association of Brazilian Businessmen and Executives in Angola, are distributed in several sectors, such as agribusiness, agriculture \& livestock, industrial food, general retail and wholesale stores, communications, vehicle dealers, civil construction, mining, shipping, and oil. In relation to exports, the Brazilian commercial agenda for Angola is very restricted, with sugar and meat being among the main products. In the opposite direction, Brazil purchases from Angola propane and liquefied butane, as well as safety and tempered glass (MRE 2012b).

Figure 4: Portugal's cluster before and after CPLP (1989-1995; 1996-2016)

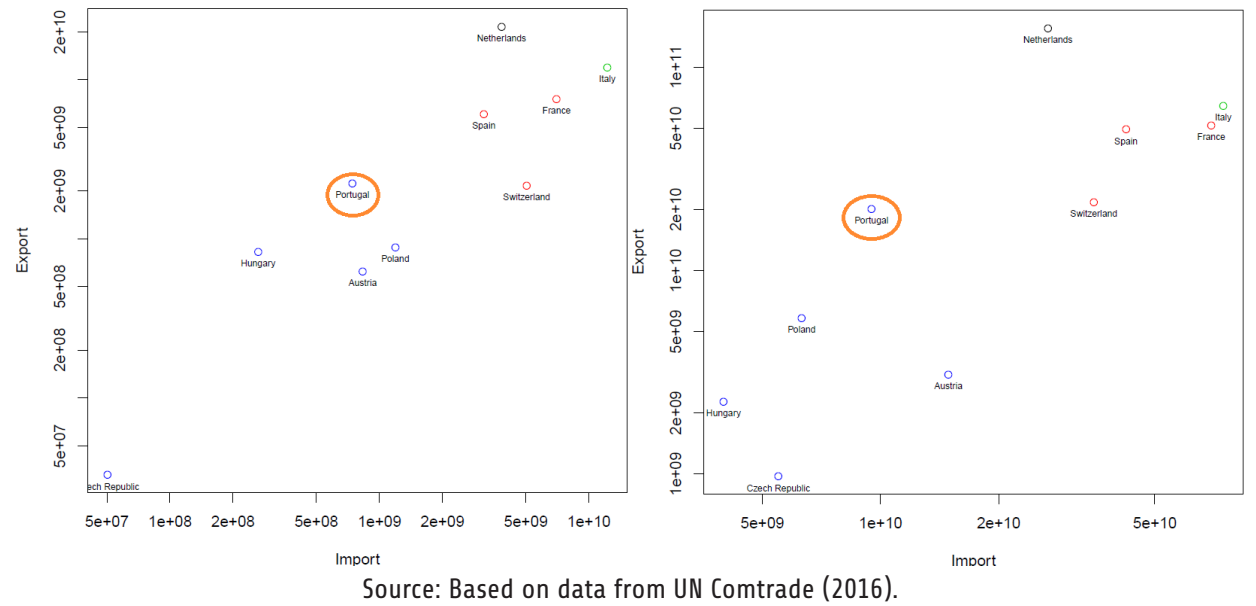

The main products of the Brazilian export agenda to Cape Verde have been sugar, meat, coffee, and iron while imports have concentrated on 'relays for voltage up to 60 volts, keyboards for automatic data-processing machines, and fixed capacitors with ceramic dielectric material' (MRE 2012c). For Guinea-Bissau, exports have been concentrated in sugar, dairy flour, tractors, eggs, and meat. Imports include cashew nuts, essential oils, and monolithic integrated circuits. As for São Tomé and Príncipe and East Timor, exports and imports are very small and only occur sporadically (MRE 2012d).

For Mozambique, except for the sale of airplanes, the export agenda follows a pattern close to the other countries in the group and is concentrated in primary products such as meat, wheat, iron, steel, and soybean oil. Imports, in turn, are generally directed towards chemical products. The difference, in this case, lies in the growing presence of Brazilian companies in the country, especially the contractors and mining companies involved in strategic building projects in Mozambique, such as the Integrated Logistics Corridor of Nacala (MRE 2012c). In this case, as Ramanzini, Mariano, and Almeida (2015) point out, one of the factors that benefited this greater investment in the country was, firstly, the forgiveness of the external debt of some African countries granted by the government administration of Lula (2003) and Dilma (2009) followed by the presence of BNDES financing lines that favoured infrastructure projects for both Angola and Mozambique. 
Thus, although it is not possible to conclude that the intra-CPLP trade is expressive, it is possible to show that government incentive actions in this direction, through diplomatic, technical, and financial support, have proven to be positive for trade, especially in the cases of Angola and, more recently, Cape Verde and Mozambique. In this same direction of promoting and facilitating trade, movement in the private sector also stands out. This has been organised through CPLP's Business Confederation, which was created in 2004 and has been seeking to play a facilitating role in business, aiming to leverage endogenous (intra-group) trade despite the low commercial complementarity between the countries.

\section{IBSA: from endogenous economic results to the trilateral co-operative arrangement}

On the IBSA incubation process, several authors (Vieira 2007; Moura 2008; Mukherjee 2009; Pereira 2010) highlight some conjuncture event and other structures that enabled the formation of the trilateral arrangement between Brazil, India, and South Africa. Recovering the decade that precedes the constitution of the IBSA, it is possible to observe that, with the opening of new international markets and diversification of partnerships, Brazil's political-diplomatic rapprochement with both countries gained a new format already in the mid-1990s following mostly trade objectives. It is also worth noting that these countries presented degrees of convergence in external positions in different multilateral forums, which, to a certain extent, assisted in the approximation process, as is the case of the commercial litigation of the Brazilian patent infringement on HIV drugs, of which India and South Africa were supportive parties (Buss and Ferreira 2009).

In addition, India indirectly involved South Africa in bilateral relations with Brazil already in 1996 related to an agreement established for using its ports on the sea for the transit of goods between Brazil and India. Another crucial point proposed by the South African President Mbeki in 2001 was to set up a group of countries formed by South Africa, Brazil, India, China, and Saudi Arabia with the purpose of being interlocutors of the countries of the South with the G-8 States (Moura 2008; Pereira 2010). This proposal did not move forward due to the changes in the international scenario after the attacks of 11 September 2001, when the attention of the world turned to a security agenda. Although the purpose of joining forces among emerging powers seeking greater weight and space in the international dialogues did not evolve in that first moment, later on it did advance in a slightly different format with purposes convergent with the previous initiative. In this context, the IBSA was born in 2003 in a meeting with the three heads of state of Brazil, India, and South Africa:

Art. 2. This is a pioneering meeting of three countries with vibrant democracies from three regions of the developing world and active on a global scale with the purpose of examining issues on the international agenda and of mutual interest. The importance and need for dialog between developing countries and nations in the South has been noted in recent years (IBSA 2003). 
In this sense, as highlighted by Faria, Nogueira, and Lopes (2012), the main IBSA work fronts are as follows: (i) the common challenges of globalisation, (ii) reform of the international system, and (iii) the dialogue on national governance. In this same direction, Pereira (2010) emphasises that the trilateral actions can be divided into two fronts: in the relationship of the countries with the other states and international organisations, and in the internal relationship between the members of the group.

As for the axis concerning the external positioning of these states, Oliveira, Onuki and Oliveira (2006), after analysing countless votes in multilateral arenas, point to the different degrees of convergence generated by the coalition in the various global agendas, with some fronts of action demonstrating a significant increase of this conformation of interests after the group's formation, as in the commercial area.

In the endogenous (intra-group) format, however, the integration of the group into the commercial arena has been considered as little explored by the trilateral and entrepreneurial initiative (Fonseca, Azevedo and Velloso 2005), although with growth possibilities if properly targeted (Schor and Onuki 2015). The number of agreements in the area of trade and investments aimed at regulating and promoting actions in this area are still low, as can be seen in Table 2. On the other hand, from the still scarce set of agreements, there are great expectations regarding the free trade agreement negotiated between MERCOSUR-India-SACU that, once feasible, can promote and bring great returns to South-South trade (Faria, Nogueira and Lopes 2012). Meanwhile, the free trade agreement between India and MERCOSUR in force since 2009 has not proved to be a differential in terms of boosting trade relations since then.

Table 2: Number of commercial/custom agreements and other agreements from Brazil with IBSA countries

\begin{tabular}{lllll}
\hline Country & $\begin{array}{l}\text { Commercial } \\
\text { agreements (until }\end{array}$ & $\begin{array}{l}\text { Other agreements } \\
\text { (until 2003) }\end{array}$ & $\begin{array}{l}\text { Commercial } \\
\text { agreements (post } \\
\text { 2003) }\end{array}$ & $\begin{array}{l}\text { Other agreements } \\
\text { (post 2003) }\end{array}$ \\
\hline South Africa & 2 & 10 & 2 & 7 \\
India & 2 & 12 & 2 & 21 \\
Multilaterals & 0 & 0 & $2^{*}$ & 18 \\
IBSA & $\mathbf{4}$ & 22 & $\mathbf{6}$ & $\mathbf{4 6}$ \\
\hline
\end{tabular}

*These agreements are being processed.

Source: Based on data from MRE (2016).

When one observes in longitudinal format the data referring to the trade of goods, it is possible to see a significant improvement in the indicators after the group's constitution. The indicator that does not show growth in this follow-up is the bilateral relationship between Brazil and South Africa, which remains at an average level of stability according to Figure 5.

In Figure 6 there is an increase in the transactions of the IBSA countries (marked) compared to their peers in terms of exports and imports, which may indicate trade gains from this agreement. However, it should be noted that despite the stability of Brazilian trade with South Africa (Figure 5), there was an increase in the trade flow of this country 
to its African and Asian peers, including passing from an inferior cluster to a higher one in terms of trade, now part of the same bloc of countries as Indonesia, Thailand, and Algeria. India also experienced significant peer-to-peer growth and, like South Africa, moved from a cluster of smaller trade flows to a larger one, approaching countries such as South Korea and Nigeria, Brazil's largest partners when considering the countries observed in this analysis.

Figure 5: Brazil's commerce flow with IBSA as a percentage of Brazil's total commerce flow

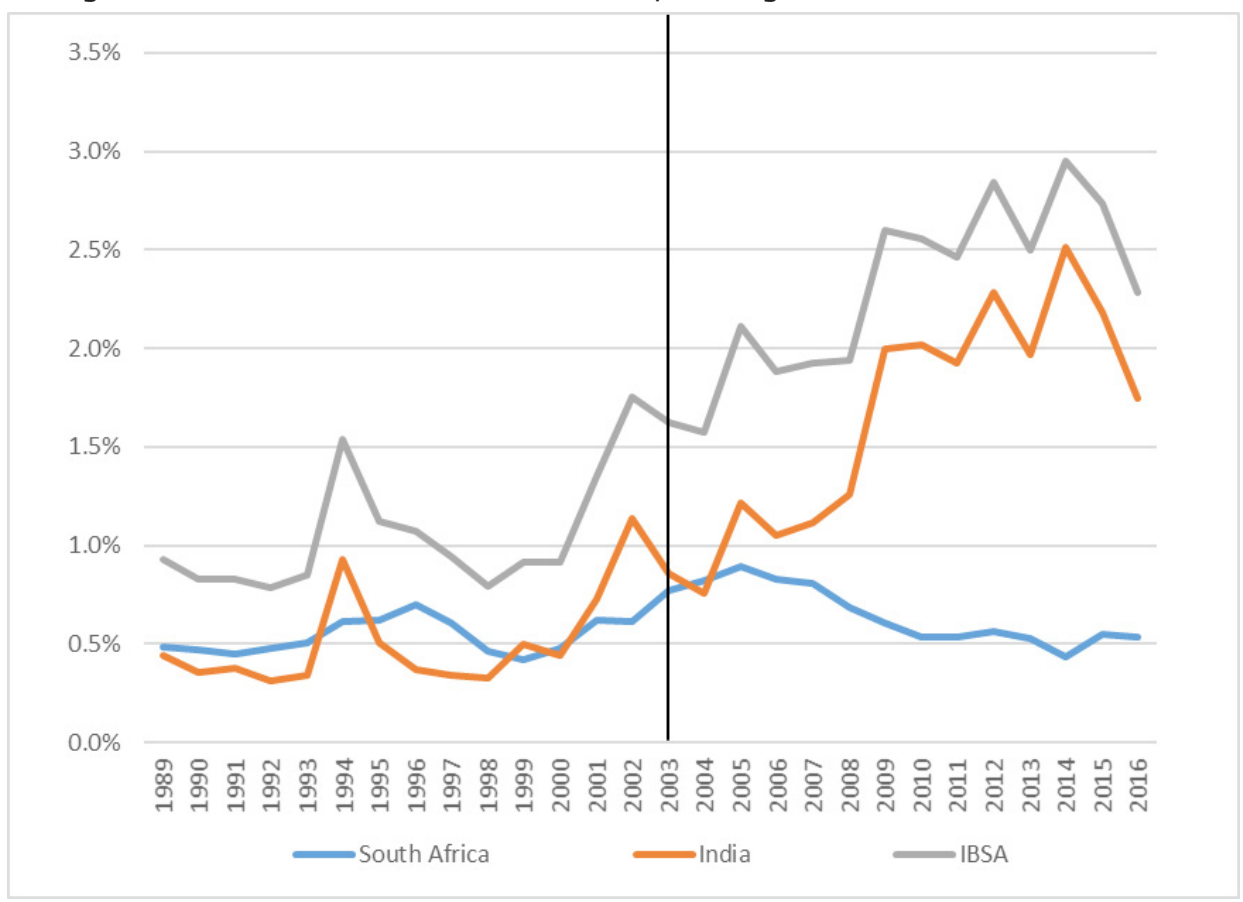

Source: Based on data from MDIC (2016).

In this sense, from the Brazilian perspective, there was also a significant leap in trade between the IBSA parties, as pointed out in the foreign trade report released by MRE in 2014, which highlights a growth of $722 \%$ in intra-IBSA trade from 2002 to 2013, while the group's trade with the world grew 398\% in the same period (MRE 2014).

Despite this, the Brazilian export agenda to South Africa is still very concentrated, with $94 \%$ of this trade involving only 100 main products (Schor and Onuki 2015), of which the main ones are as follows: '(i) edible cuts and offal of rooster, hen, chicken, frozen [...]; (ii) other vehicles with an explosion engine [...]; (iii) refined sugar from cane/ beets [...]; (iv) gold bullion not for monetary use [...]' (MRE 2012a). As for Brazilian imports from South Africa, Schor and Onuki (2015) observed that over the years the degree of concentration of products also advanced in this direction, going from $79 \%$ in 2001 to $85 \%$ in 2011. The main products on this list are '(i) Anthracite coal, not agglomerated; (ii) herbicides' (MRE 2012a). 
Figure 6: IBSA country cluster, before and after the agreement (1989-2002; 2003-2016)

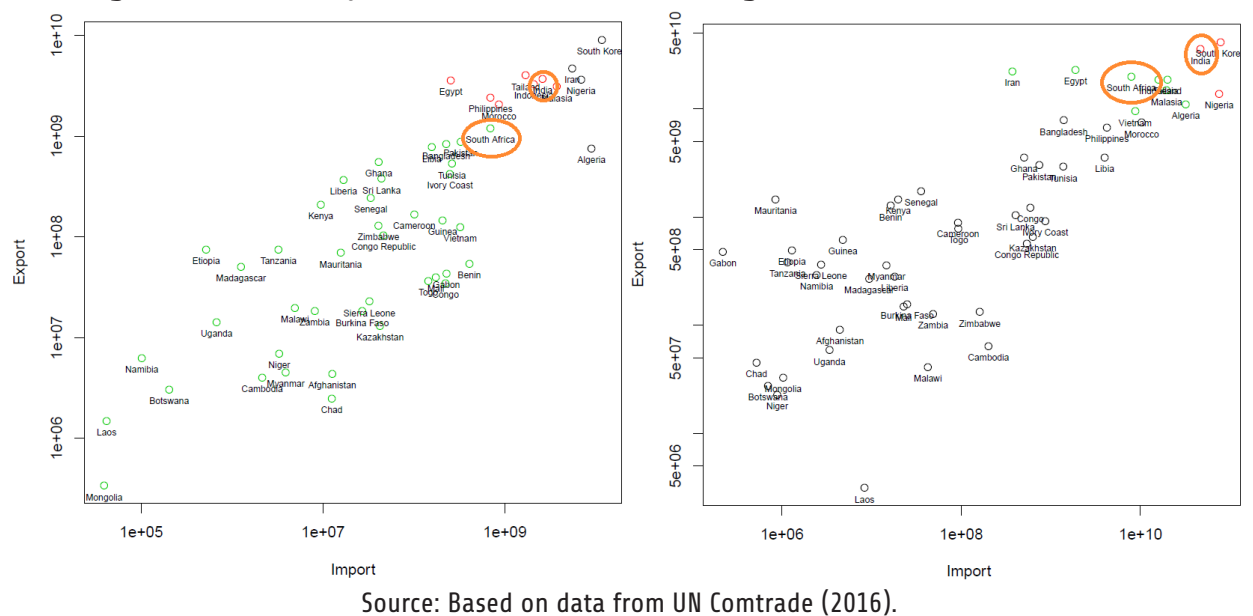

On Brazil-India bilateral trade, unlike South Africa, the balance is negative for Brazil, which means that the country imports more than it exports to India. When the characteristic of the list is observed, a high concentration of trade can also be found in a few products, although with a tendency towards deconcentration, as presented by Schor and Onuki (2015). In this study, they revealed that in 2001 the concentration was in 100 products representing 99\% of Brazilian exports to India, while in 2011 this same number came to represent $94 \%$ of the total. In the comparison of the same two moments, exports from India to Brazil also followed the trend of deconcentration, dropping from $94 \%$ of the total in 2001 to $86 \%$ in 2011 .

Mirroring the Brazilian exports to these countries, Table 3 shows the main Brazilian companies with a participation in the markets of India and South Africa.

Table 3: Main firms with business in India and South Africa

\begin{tabular}{lllll}
\hline Petrobras & Embraer & Vale & Gerdau & Suzano \\
\hline ArcelorMittal Brasil & $\begin{array}{l}\text { Cooperativa dos } \\
\text { Produtores de Cana } \\
\text { de Açucar }\end{array}$ & Usiminas & $\begin{array}{l}\text { General Motors } \\
\text { Brasil }\end{array}$ & Volkswagen Brasil \\
\hline Souza Cruz & Weg & Scania & Cargill & BRF \\
\hline JBS & Cosan & Man Latin & Caterpillar & Marcopolo \\
\hline & & Source: Data based on MRE (2012d).
\end{tabular}

A preponderance can be seen of companies in the automotive sector, sugar cane, food derived from poultry, and ores, showing a conformity with the main products of the export agenda. In this context, the presence of Marcopolo in a joint venture with Tata Motors near Bangalore, India, stands out. Despite this presence, Brazil's foreign direct investment indexes in these countries are low. According to data from the institutional website of the Brazilian Central Bank, South Africa appears in $36^{\text {th }}$ place in the FDI ranking with a total of 
US $\$ 179$ m between 2006 and May 2016, while India appears in the space labelled as 'other countries', which means that it is irrelevant when viewed together with the total investments.

This behaviour is corroborated by the low degree of complementarity between the economies, which are mainly commoditised. There are some sectors, however, that escape this rule according to Carneiro (2012), and the ones that deserve attention are those of medium technology and resource-intensive manufactures. This situation is reflected in the IBSA Business Forum, which takes place in parallel with the IBSA meetings. Signed in 2005, the trade priorities explored include financial services and the mining, pharmaceuticals, health, agriculture, energy, information technology, infrastructure, tourism, automotive, marine, and aviation sectors (IBSA 2005). Furthermore, there is support for creating the free trade zone between MERCOSUR-India-SACU. On the other hand, it seems that the forum's efforts are stagnating, as is the IBSA itself, considering that the last meeting took place in 2011 and the one that was scheduled for 2013 did not take place.

\section{Final considerations}

This article analyses the economic and financial aspects of two international co-operative arrangements from the Brazilian perspective: the IBSA and the CPLP. To do so, using as a base the concept of interdependence between states (Keohane and Nye 1998) and based on the premise that institutions have an impact on the flow and direction of international trade (North 1990, 2003; Perera 2015), documents and articles on these arrangements were studied, together with quantitative data, thus providing a longitudinal analysis on them.

The result was a positive relationship in both cases between the arrangement and the increase in trade and investments. Therefore, it can be said that, despite the essentially non-economic nature of these groups, they have shown a spillover from political and cultural relations into economic transactions. When shaping the institutional environment, these results reinforce the view that the agreements have the property of providing greater acceptance and giving stronger credibility to the performance of these companies at an international level (Perera 2015). Also, as reinforced by Williamson (1975), these governance structures, by defining the 'rules of the game', tightening diplomatic ties, and providing the exchange of interests, would generate incentives for economic activity. It should be noted, however, that although there has been a commercial increase in the two cases investigated, they are still incipient formats. Because of this, other factors that may have influenced this result cannot be ignored, which means that a correlation was found between the variables, but it is not possible to categorically infer a causal relation between them.

Thus, despite the advances observed in trade and investment indicators, it is worth noting that there is still a great deal of co-operation between the parties that did not receive special attention from the Brazilian government, nor from more assertive and structured initiatives within the groups analysed. Especially in the case of the CPLP, direction is also given by the incentives of the Brazilian government for some of the countries of the group while the others are diplomatically relegated to secondary positions. In the case of the IBSA, there are several interests and convergences in the group, but the trade and 
investment relations, although they have grown over time, are still not very expressive and have significant room for advancement.

Based on this study, it is proposed that the Brazilian trade with these countries be investigated more deeply in future research in order to analyse the performance of Brazilian companies, the economic complementarity, and opportunities, along with if and how much the role of the state was important for this movement through agreements, arrangements, and other instruments. Likewise, analyses that aim to call attention to the phases of the implementation of foreign policy and the evaluation of the results will help to complement an area of study that has focused mainly on understanding the first stages of the process, such as formulation and decision.

\section{References}

Buss, Paulo and José Roberto Ferreira. 2009. 'IBAS: coordenação e cooperação entre países em desenvolvimento'. In III Conferência Nacional de Política Externa e Política Internacional: O Brasil no mundo que vem aí. Brasília: Fundação Alexandre de Gusmão, pp. 63-80.

Carneiro, Flavio Lyrio. 2012. Complementaridade da pauta e oportunidades de aproximação comercial do Brasil com os demais BRICS. Brasília: Boletim de Economia e Política Internacional, IPEA.

Castells, Manuel. 2005. A sociedade em rede. 8th ed. São Paulo: Paz e Terra.

Cherchye, Laurens and Arnt Verriest. 2016. 'The impact of home-country institutions and competition on firm profitability'. International Business Review 25 (4): 831-46.

Community of Portuguese Language Countries (CPLP). 2007. Estatutos da comunidade dos países de língua portuguesa. At https://www.cplp.org/Files/Filer/Documentos\%20Essenciais/Estatutos_ CPLP_REVLIS07.pdf [Accessed on 20 June 2016].

Community of Portuguese Language Countries (CPLP). 2010. Declaração sobre 'cooperação, desenvolvimento e democracia na era da globalização'. At https://www.cplp.org/Admin/Public/DWSDownload.aspx?File=\%2FFiles\%2FFiler\%2Fcplp\%2FCCEG\%2FIII_CCEG\%2FDECLARA\%EF\%B F\%BD\%EF\%BF\%BDOSOBRECOOPMaputo2000.pdf [Accessed on 20 June 2016].

Community of Portuguese Language Countries (CPLP). 2012. Declaração de Luanda. I. ${ }^{a}$ reunião de ministros do comércio da comunidade dos países de língua portuguesa. At https:/www.cplp.org/ Admin/Public/DWSDownload.aspx?File=\%2FFiles\%2FFiler\%2Fcplp\%2Fredes\%2FCom\%C3\%A9 rcio\%2F5+Declaracao+Final+I+Reuniao+MINCO+CPLP+(vers\%C3\%A3o+final).pdf [Accessed on 20 June 2016].

Coppedge, Michael, Angel Alvarez and Claudia Maldonado. 2008. 'Two persistent dimensions of democracy: contestation and inclusiveness'. Journal of Politics 70 (3): 632-647.

Faria, Carlos Aurélio Pimenta, Joana Laura Marinho Nogueira and Dawisson Belém Lopes. 2012. 'Coordenação Intragovernamental para a Implementação da Política Externa Brasileira: O Caso do Fórum IBAS'. DADOS - Revista de Ciências Sociais 55 (1): 173-220.

Ferreira Filho, José Alexandre and Thales Cavalcanti Castro. 2012. 'O papel das instituições formais e informais no crescimento econômico: Brasil, Rússia, Índia e China em perspectiva comparada' Paper presented at the III Seminário sobre Pesquisas em Relações Econômicas Internacionais. Brasília, 29-30 March 2011. 
Fonseca, Renato, Marcelo S Azevedo and Edson Velloso. 2005. O potencial de comércio entre Brasile Índia: um exame com base nas estruturas de vantagem comparativa. Brasília: CNI.

Globerman, Steven and Daniel M Shapiro. 1999. 'The impact of government policy on foreign direct investment: The Canadian experience. Journal of International Business Studies 30 (3): 513-532.

Grein, Andreas F, S Prakash Sethi and Lawrence G Tatum. 2010. 'Dynamic Analysis of Country Clusters, the Role of Corruption, and Implications for Global Firms'. Journal of Economics and Business 13 (2): 33-60.

Guimarães, Samuel Pinheiro. 1998. 'Desafios e dilemas dos grandes países periféricos: Brasil e Índia'. Revista Brasileira de Política Internacional 41 (1): 109-132.

Hanson II, John R. 1999. 'Culture shock and direct investment in poor countries'. Journal of Economic History 59 (1): 1-16.

Harris, John, Janet Hunter and Colin M Lewis. 2003. 'Introduction: development and significance of NIE'. In John Harris, Janet Hunter and Colin M Lewis (eds), The new institutional economics and Third World development. London/New York: Routledge, pp.1-13.

India-Brazil-South Africa (IBSA). 2003. Declaração de Brasília, 6 June 2003.

2005. IBSA Trade and Investment Working Group. At http://www.ibsa-trilateral.org/ [Accessed on 20 June 2016].

Ishido, Hikari. 2016. 'A new institutional approach to Japanese firms' foreign direct investment under free trade agreements'. Institute of Developing Economies Discussion Paper 608.

Keohane, Robert O and Joseph S Nye. 1998. Poder e interdependencia: La política mundial en transición. Buenos Aires: Grupo Editor Latinoamericano.

Krasner, Stephen D. 2012. 'Causas Estruturais e consequências dos regimes internacionais: regimes como variáveis intervenientes'. Revista de Sociologia e Política 20 (42): 93-110.

Lee, Seung-Hyun, Mike W Peng and Jay B Barney. 2007. 'Bankruptcy law and entrepreneurship development: a real options perspective'. Academy of Management Review 32 (1): 257-272.

Leite, Patrícia Soares. 2011. O Brasil e a Cooperação Sul-Sul em três momentos: os governos Jânio Quadros/João Goulart, Ernesto Geisel e Luiz Inácio Lula da Silva. Brasília: Fundação Alexandre de Gusmão.

Lima, Maria Regina Soares. 2009. 'A iniciativas IBAS e a cooperação Sul-Sul: desafios intelectuais e possibilidades políticas'. In Maria Regina Soares de Lima and Monica Ellen Seabra Hirst (eds), Brasil, Índia e África do Sul. São Paulo: Paz e Terra, pp. 7-28.

Meyer, Klaus E. 2001. 'Institutions, transaction costs, and entry mode choice in Eastern Europe'. Journal of International Business Studies 32 (2): 357-367.

Ministry of Foreign Relations of Brazil (MRE). 2012a. Guia de negócios: África do Sul. Brasília. At https://investexportbrasil.dpr.gov.br/arquivos/Publicacoes/ComoExportar/GNAfricaSul.pdf [Accessed on 20 June 2016].

2012b. Como exportar: Angola. Brasília. At https://investexportbrasil.dpr.gov.br/arquivos/ Publicacoes/ComoExportar/CEXAngola.pdf [Accessed on 20 June 2016].

2012c. Guia de negócios: Cabo Verde. Brasília. At https://investexportbrasil.dpr.gov.br/arquivos/Publicacoes/ComoExportar/GNCaboVerde.pdf [Accessed on 20 June 2016].

2012d. Guia de negócios: São Tomé e Príncipe. Brasília. At https://investexportbrasil.dpr.gov. br/arquivos/Publicacoes/ComoExportar/GNSaoTomePrincipe.pdf [Accessed on 20 June 2016]. 
. 2013. Como exportar: Portugal. Brasília. At https://investexportbrasil.dpr.gov.br/arquivos/ Publicacoes/ComoExportar/CEXPortugal.pdf [Accessed on 20 June 2016]. 2014. Relatório de comércio exterior. Brasília.

. 2014. Sistema de Atos Internacionais. Brasília. At http://dai-mre.serpro.gov.br [Acessed on 20 June 2016].

Ministry of Development, Industry and Foreign Trade (MDIC). 2016. AliceWeb System of information access. Brasília. At http://aliceweb.mdic.gov.br [Accessed on 20 June 2016].

Moura, Gilberto F G. 2008. 'O diálogo Índia, Brasil, África do Sul-IBAS: balanço e perspectivas'. In III Conferência Nacional de Política Externa e Política Internacional: O Brasil no mundo que vem aí. Brasília: Fundação Alexandre de Gusmão, pp. 7-30.

Mudambi, Ram and Pietro Navarra. 2002. 'Institutions and international business: a theoretical overview'. International Business Review 11 (6): 635-646.

Mukherjee, Aditya. 2009. 'IBSA: Overview and perspectives - Historical roots of the common challenges of India, Brazil and South Africa'. In Conferência Nacional de Politica Externa e Politica Internacional: O Brasil no mundo que vem aí. Brasília: Fundação Alexandre de Gusmão, pp. 111-126.

North, Douglass C. 1990. Institutions, institutional change and economic performance. Cambridge: Cambridge University Press.

North, Douglass C. 2003. 'The new institutional economics and third world development'. In John Harris, Janet Hunter and Colin M Lewis (eds), The new institutional economics and Third World development. London/New York: Routledge, pp. 17-26.

Oliveira, Amâncio Jorge Nunes, Janina Onuki and Emmanuel de Oliveira. 2006. 'Coalizões Sul-Sul e Multilateralismo: Índia, Brasil e África do Sul'. Contexto Internacional 28 (2): 465-504.

Peng, Mike W. 2006. Global Strategy. Cincinnati, Ohio: South-Western Thomson.

Peng, Mike W and Peggy Sue Heath. 1996. 'The growth of the firm in planned economies in transition: institutions, organizations, and strategic choices'. Academy of Management Review 21 (2): 492-528.

Penna Filho, Pio. 2008. O Brasil e a África do Sul: o arco atlântico da Política Externa Brasileira (1918-2000). Porto Alegre: FUNAG/MRE.

Pereira, Analúcia Danilevicz. 2010. 'As relações entre África do Sul e Brasil: do impacto da globalização à constituição do IBAS'. Século XXI 1 (1): 85-106.

Perera, Pramuk. 2015. 'Influence of international trade agreements on international business: a conceptual model'. Journal of East-West Business 21 (3): 205-232.

Pimentel, José Vicente de Sá. 2000. 'Relações entre o Brasil e a África subsaárica'. Revista Brasileira de Política Internacional 43 (1): 5-23.

Pohlman, Marcelo Coletto. 2007. 'Análise de Conglomerados'. In Edilson Paulo, Luiz J Corrar and José Maria Dias Filho (eds.), Análise Multivariada. São Paulo: Atlas.

Ramanzini Júnior, Haroldo, Marcelo Passini Mariano and Rafael Augusto Ribeiro de Almeida. 2015. 'As diferentes dimensões da cooperação sul-sul na política externa brasileira'. In Haroldo Ramanzini Júnior and Luis Fernando Ayerbe (eds), Política externa brasileira, cooperação sul-sul e negociações internacionais. São Paulo: Cultura Acadêmica, pp. 15-52.

Rizzi, Kamilla Raquel. 2016. 'Relações Brasil-PALOP: 40 anos de cooperação para o Desenvolvimento no Atlântico Sul (1974/75-2015)'. Revista Brasileira de Estudos Africanos 1 (1): 143-167. 
Santana, Ivo. 2003. 'O despertar empresarial brasileiro para o mercado africano nas décadas de 1970 a 1990'. Contexto Internacional 25 (1): 139-195.

Saraiva, José Flávio Sombra. 2002. 'Política exterior do Governo Lula: o desafio africano'. Revista Brasileira de Política Internacional 45 (2): 5-25.

Saraiva, Miriam Gomes. 2007. 'As estratégias de cooperação Sul-Sul nos marcos da política externa brasileira de 1993 a 2007’. Revista Brasileira de Política Internacional 50 (2): 42-59.

Schor, Adriana and Janina Onuki. 2015. 'Política externa brasileira e a coalizão IBAS: comércio e inserção internacional'. In Haroldo Ramanzini Júnior and Luis Fernando Ayerbe (eds), Política externa brasileira, cooperação Sul-Sul e negociações internacionais. São Paulo: Cultura Acadêmica, pp. 115-40.

Scott, W Richard. 2008. Institutions and organizations: ideas and interests. 3rd ed. Thousand Oaks, CA: Sage.

Tong, Tony W, Jeffrey J Reuer and Mike W Peng. 2008. 'International joint ventures and the value of growth options'. The Academy of Management Journal 51 (5): 1014-1029.

UN Comtrade. 2016. 'UN Comtrade: International Trade Statistics'. At https://comtrade.un.org/ data/ [Accessed in 22 April 2017].

Vahalík, Bohdan and Michaela Staníčková. 2016. 'Key factors of foreign trade competitiveness: comparison of the EU and BRICS by factor and cluster analysis'. Society and Economy 38 (3): 295-317.

Vieira, Maíra Baé Baladão. 2007. Relações Brasil-Índia (1991-2006). PhD Thesis, Universidade Federal do Rio Grande do Sul, Rio Grande do Sul, Brazil.

Williamson, Oliver E. 1975. Markets and hierarchies: analysis and antitrust implications. New York: Free Press.

Wolfson, Murray, Zagros Madjd-Sadjadi and Patrick James. 2004. 'Identifying National Types: A Cluster Analysis of Politics, Economics, and Conflict'. Journal of Peace Research 41 (5): 607-623.

\section{About the authors}

Ariane Roder Figueira has a PhD in Political Sciences (major in International Relations) from the University of São Paulo (USP) and a Bachelor in Social Sciences from Paulista State University (UNESP). She is a professor of International Business and Public Administration at the Federal University of Rio de Janeiro (UFRJ) and a researcher at the COPPEAD's Center for International Business Studies (CENI) and COPPEAD's Center of Innovation and Sustainability. Her presentations at conferences, papers published in academic journals, and the research she conducts are related to the fields of international relations, foreign trade, corporate sustainability, foreign policy, political institutions, political parties, decision-making processes and international business. She has published two books in the area: Introdução à Analise de Política Externa (Editora Saraiva, 2011) and Negócios Internacionais: perspectivas brasileiras (Editora Campus, 2014).

Bernardo Frossard da Silva-Rêgo is a $\mathrm{PhD}$ candidate in International Business at the COPPEAD School of Business. He graduated in business at the Federal University of Rio de Janeiro (UFRJ), with a master's degree in international business from the COPPEAD 
School of Business. Presently, he is a researcher at COPPEAD's Center for International Business Studies (CENI) and a temporary researcher at Conectas Direitos Humanos, where he studies the relationship between business organisations and governments, highlighting the development banks' role in the internationalisation process of companies. He also researches heavy construction companies and their relationship with the state, and the differences in the institutional environment in both developed and emerging countries.

\title{
A Face Econômica dos Arranjos Cooperativos Internacionais: os Casos IBAS e CPLP
}

\begin{abstract}
Resumo: A formação de arranjos cooperativos internacionais, com diferentes escopos e estruturas, tem sido crescente no sistema internacional. O Brasil tem participado com frequência desses grupos, compondo um quadro diplomático complexo, onde se convive e interage com blocos regionais, organizações internacionais, grupos e coalizões. Diante disso, o propósito deste artigo foi investigar os efeitos comerciais provocados pelos arranjos cooperativos internacionais, observando particularmente, a partir da ótica brasileira, dois casos: o IBAS (Grupo Índia-Brasil-África do Sul) e a CPLP (Comunidade de Países de Língua Portuguesa). Os construtos teóricos da Nova Economia Institucional subsidiaram a interpretação dos dados, assim como ganhou destaque a literatura que explora novos mecanismos de inserção externa de países emergentes, através da diplomacia orientada para o eixo Sul-Sul. A metodologia empregada foi do estudo de dois casos, reunindo indicadores tanto quantitativos como qualitativos, fundamentados, sobretudo, nos relatórios oficiais do governo brasileiro e de análises setoriais produzidas por entidades de classes. A evolução comercial intrabloco foi realizada mediante uma análise de cluster considerando as exportações e as importações de cada um dos casos investigados em relação ao Brasil. Os resultados encontrados apontaram para um incremento das transações comerciais entre os Estados-membros.
\end{abstract}

Palavras-chave: Arranjos Cooperativos Internacionais; IBAS; CPLP; Teoria Institucional; Sul-Sul; Análise de Cluster; Comércio.

Received on 12 April 2017, and approved for publication on 8 August 2017.

\section{(c)) BY-NC} https://creativecommons.org/licenses/by-nc/4.0/ 